\title{
PENERAPAN MANAJEMEN SUMBER DAYA MANUSIA (MSDM) DALAM MENINGKATKAN KINERJA GURU DI SMK YASMIDA AMBARAWA KABUPATEN PRINGSEWU
}

\author{
Nurul Qoni'ah, Dedi Irawan, Eri Purwanti \\ Jl. Raya Wonokriyo Gadingrejo Pringsewu \\ Email: stitpringsewu@gmail.com
}

\begin{abstract}
His study aims to improve teacher performance in SMK YASMIDA Ambarawa Kab. Pringsewu through the application of Human Resource Management. This research is a qualitative research by using a benchmark as a barometer of truth. Objects studied at SMK YASMIDA Ambarawa Kab. Pringsewu. While the data collection techniques applied by using: Interview / interview to the principal, the division of questionnaires / questioners to students and teachers, as well as documentation as supporting research results. The analytical technique used by the authors in this study is descriptive qualitative analysis. From the analysis of the data can be concluded that: The results of research on the implementation process of Human Resource Management (MSDM) is Applying Planning, Organizing, Actuating, and Controlling. Once known the application of POAC hence can be seen an improvement on teacher performance of SMK YASMIDA Ambarawa Kab. Pringsewu is calculated from 2014, 2015 and 2016. The improvement of teacher performance can be seen from the improvement of presentation of the results of implementation on each statement, with the final result obtained as follows: (a) the result of questionnaire distribution to students with the average obtained in the year 2014 with a presentation value of $62 \%$, in 2015 with a presentation rate of $77 \%$ and in 2016 with an $89 \%$ presentation. (B) the results of questionnaire distribution to teachers with an average score obtained in 2014 with a presentation value of $60 \%$, in 2015 with a presentation value of $68 \%$ and in 2016 with a presentation value of $89 \%$.
\end{abstract}

\begin{abstract}
Abstrak
Penelitian ini bertujuan untuk meningkatkan kinerja guru di SMK YASMIDA Ambarawa Kab. Pringsewu melalui penerapan Manajemen Sumber Daya Manusia. Penelitian ini merupakan penelitian kualitatif dengan menggunakan tolak ukur sebagai barometer kebenarannya. Objek yang diteliti yaitu di SMK YASMIDA Ambarawa Kab. Pringsewu. Sedangkan tehnik pengumpulan data yang diterapkan dengan menggunakan: Interview / wawancara kepada kepala sekolah, pembagian angket/questioner kepada siswa dan guru, serta dokumentasi sebagai penunjang hasil penelitian. Adapun tehnik analisis yang digunakan penulis dalam penelitian ini adalah analisis deskriptif kualitatif. Dari analisis data tersebut dapat disimpulkan bahwa: Hasil penelitian pada proses penerapan Manajemen Sumber Daya Manusia (MSDM) ini menerapakan Planning, Organizing, Actuating, dan Controlling. Setelah diketahui penerapan POAC maka dapat diketahui adanya peningkatan pada kinerja guru SMK YASMIDA Ambarawa Kab. Pringsewu terhitung dari tahun 2014, 2015 dan 2016. Peningkatan kinerja guru ini dapat dilihat dari peningkatan presentasi hasil penerapan pada setiap pernyataan, dengan hasil akhir yang diperoleh yaitu sebagai berikut: (a) hasil pembagian angket kepada siswa dengan rata-rata yang didapat pada tahun 2014 dengan nilai presentasi 62\%, pada tahun 2015 dengan nilai presentasi $77 \%$ dan pada tahun 2016 dengan nilai presentasi 89\%. (b) hasil pembagian angket kepada guru dengan nilai rata-rata yang diperoleh pada tahun 2014 dengan nilai presentasi 60\%, pada tahun 2015 dengan nilai presentasi $68 \%$ dan pada tahun 2016 dengan nilai presentasi $89 \%$.
\end{abstract}

Kata Kunci: Manajemen Sumber Daya Manusia (MSDM), Kinerja Guru. 


\section{A. PEndahuluan}

Tanpa adanya peraturan pemerintah Republik Indonesia yang jelas dan sesuai dengan Undang-Undang Dasar Negara Indonesia, pendidikan di Negara Indonesia tidak akan berjalan dan tidak akan terselenggarakan sesuai harapan bangsa. Bangsa Indonesia sangat mendukung sepenuhnya pada proses pendidikan dengan menerapkan tujuan mencerdaskan anak bangsa serta mendidik peserta didik untuk menggapai cita-cita yang diharapkan bersama. Dengan menerapkan tujuan dan cita-cita bangsa Indonesia, maka perlu adanya perealisasian proses pendidikan yang sesuai dan tersetruktur mengacu pada peraturan Pemerintah Republik Indonesia dan Undang-undang Dasar 1945.

Dibawah ini peraturan pemerintah Republik Indonesia dan Undang-undang Dasar 1945 tentang pendidikan yang berbunyi:

"Menurut Undang-undang dan Peraturan Pemerintah RI pasal I, yang berbunyi: Pendidikan merupakan usaha sadar dan terencana untuk mewujudkan usaha belajar dan proses pembelajaran agar peserta didik secara aktif mengembangkan potensi dirinya untuk memiliki kecerdasan, akhlak mulia, serta ketrampilan yang diperlukan dirinya, masyarakat, bangsa dan Negara".

Melihat pengertian pendidikan diatas, untuk menciptakan pendidikan yang afektive dan berkualitas sesuai Undang-undang dan peraturan pemerintah RI, Lembaga Pendidikan menerapan Manajemen Sumber Daya Manusia (MSDM). Dengan adanya penerapan Manajemen Sumber Daya Manusia (MSDM) pendidikan dapat menciptakan bakat dan minat siswa sesuai potensi yang dimiliki peserta didik sehingga menciptakan kecerdasan baik kecerdasan emosional maupun kecerdasan intelektualnya. Sebelum penerapan Manajemen Sumber Daya Manusia (MSDM) ini diterapkan, perlu diketahui pengertian dari manajemen itu sendiri. Adapun pengertian "Manajemen adalah proses perencanaan, pengorganisasian, memimpin dan mengawasi usaha-usaha dari anggota organisasi dan sumber-sumber organisasi lainnya untuk mencapai tujuan yang telah ditetapkan".

Setelah mengetahui pengertian manajemen menurut Stoner, penulis dapat mengambil inti dari pengertian tersebut yaitu, bahwa yang dimaksud dengan manajemen adalah suatu proses yang direncanakan oleh suatu kelompok organisasi guna untuk mencapai sasaran atau tujuan yang diharapkan bersama dalam jangka waktu yang ditetapkan.

Sedangakan pengertian "Manajemen Sumber Daya Manusia (MSDM) adalah pengembangan dan pemanfaatan pegawai dalam rangka tercapainya tujuan dan sasaran individu, organisasi, masyarakat, bangsa dan internasional yang afektive."

Setelah mengetahui pengertian Manajemen Sumber Daya Manusia menurut Moses N. Kingundu, penulis berpendapat bahwa pengertian Manajemen Sumer Daya Manusia (MSDM) adalah suatu proses penerapan mengembangkan dan memanfaatkan tenaga kerja atau organisasi dalam rangka pencapaian tujuan bersama sesuai apa yang diharapkan kelompok organisasi maupun masyarakat.

Melihat pengertian diatas, bahwa Manajemen Sumber Daya Manusia (MSDM) merupakan pendekatan terhadap manajemen manusia melalui proses perencanaan, pengorganisasian, memimpin dan pengawasan. Pendekatan manajemen manusia didasarkan pada nilai potensi manusia terhadap organisasi yang ada pada Lembaga Pendidikan. Manusia merupakan sumber daya yang sangat penting dalam organisasi, dengan adanya manusia, efektifitas organisasi dapat terealisasikan sesuai yang diharapkan pada Lembaga Pendidikan.

Menurut buku yang dikarang oleh Ambar Teguh Sulistiani Rosidah bahwasanya Aktivitas Manajemen Sumber Daya Manusia (MSDM) itu berupa usaha peningkatan produktivitas, seperti pengadaan / rekrutment, pengembangan, pemberian imbalan, motivasi, mutasi dan pemberhentian.

Dengan adanya aktivitas Manajemen Sumber Daya Manusia (MSDM) kinerja pegawai dan karyawan dalam proses perekrutan pasti mencari tenaga kerja yang sesuai dengan kebutuhan Lembaga Pendidikan ataupun perusahaan, dengan demikian pekerja mampu bekerja sama guna mencapai tujuan agar saling menguntungkan serta apabila ada kinerja pegawai yang tidak sesuai dengan tujuan Lembaga Pendidikan atau perusahaan, maka akan diperhentikan.

Personalia Manajemen Sumber Daya Manusia (MSDM) yang ada pada Lembaga Pendidikan berkaitan dengan kinerja guru yang ada pada Lembaga Pendidikan. Guru yang mempunyai kualitas dan kuantitas yang tinggi akan dijadikan sebagai tolak ukur kinerja guru yang lain sesuai dengan prestasi kerja kinerja guru yang dimilikinya. Profesionalisme guru sangat mendukung untuk keberhasilan peserta didik yang menjadi keluaran yang ada pada Lembaga Pendidikan sesuai visi dan misi yang diterapkan.

Melihat uraian yang sudah dijelaskan diatas, agar lebih jelasnya penulis melampirkan pengertian kinerja menurut Tjutju dan Suwarto serta pengertian guru menurut Barnawi dan Muhammad Arifin.

Adapun hasil pengertian menurut tokoh yang disebutkan diatas diantaranya:"Kinerja merupakan prestasi nyata yang ditampilkan 
seseorang setelah yang bersangkutan menjalankan tugas dan perannya dalam organisasi" Sedangkan "Guru merupakan pendidik proffessional dengan tugas utama mendidik, mengajar, membimbing, melatih, menilai dan mengevaluasi hasil pembelajaran siswa."

Melihat pengertian kinerja dan guru diatas, dapat penulis simpulkan bahwa kinerja guru merupakan kemampuan yang dimiliki oleh pendidik dalam melaksanakan tugas dan kewajibannya di lembaga pendidikan. Tanpa adanya guru proses belajar mengajar tidak akan berjalan dan bahkan tidak akan terselenggarakan. Ada yang berpendapat bahwa guru itu harus di gugu dan ditiru, dalam artian setiap guru selalu mengajar dan mengarahkan serta memberikan yang terbaik kepada semua peserta didiknya.

Penjelasan Hadist Rasulullah SAW, sebagai penguat kemampuan kinerja guru yang sesuai dan harus diterapkan, yang berbunyi:

$$
\text { اذ او سد الا مر الى غير ا هله فانتظر السا عة }
$$

Artinya: "Jika suatu urusan diserahkan kepada yang bukan ahlinya, maka tunggulah kehancurannya". (HR. Bukhori).

Kutipan hadist diatas pada intinya bahwa seorang guru harus mengajar sesuai keilmuan yang dimilikinya, dan seandainya ada guru yang mengajar tetapi tidak sesuai dengan keilmuannya, out-put yang dihasilkan kurang maksimal atau tidak sesuai dengan yang diharapkan.

"Menurut Undang-undang No. 14 Tahun 2005 pasal 20, tugas dan kewajiban guru antara lain:

1. Merencanakan pembelajaran, melaksanakan proses pemebelajaran yang bermutu, serta menilai dan mengevaluasi hasil pembelajaran.

2. Meningkatkan dan mengembangkan kualifikasi akademik dan kompetensi secara berkelanjutan sejalan dengan perkembangan ilmu pengetahuan, teknologi dan seni.

3. Bertindak obyektive dan tidak diskriminative atas dasar pertimbangan jenis kelamin, agama, atau latar belakang keluarga dan status sosial ekonomi peserta didik dalam pembelajaran,

4. Menjunjung tinggi peraturan perundangundang, hukum dan kode etik guru, serta nilai-nilai agama dan etika,

5. Memelihara dan memupuk persatuan dan kesatuan bersama."

Melihat tugas dan kewajiban guru menurut Undang-undang yang sudah disebutkan diatas, bahwa kinerja guru sangat dibutuhkan dalam proses belajar mengajar, tanpa adanya professionalisme guru aktifitas belajar mengajar tidak akan berjalan sesuai yang diharapkan.

SMK YASMIDA Ambarawa Kab. Pringsewu memiliki 83 Tenaga Pendidik dan Kependidikan, 54 Guru Laki-laki dan 29 Guru Perempuan, dengan tingkat pendidikan terakhir untuk SMA berjumlah 13 Orang, Strata I berjumlah 68 Orang, Setrata II berjumlah 1 Orang dan Strata III berjumlah 1 Orang. Guru tersebut berstatus Guru honorer dan ada beberapa Guru yang sudah berstatus sertifikasi. Melihat jumlah guru yang ada di SMK YASMIDA Ambarawa Kab. Pringsewu dengan berbagai tingkat pendidikan yang berfariasi pastinya kinerja guru keseluruhanya tidak sama dan memiliki potensi kinerja masing-masing.

Penulis memilih lokasi penelitian di SMK YASMIDA Ambarawa Kab. Pringsewu dengan alasan letaknya yang setrategis dan terjangkau dari tempat peneliti, SMK YASMIDA Ambarawa termasuk kategori Sekolah Rujukan ke-3 yang ada di Profinsi Lampung. Dengan adanya penerapan Manajemen Sumber Daya Manusia (MSDM) akan tercipta peningkatan kapasitas pada kinerja guru.

SMK YASMIDA Ambarawa Kab. Pringsewu sudah menerapkan Manajemen Sumber Daya Manusia (MSDM), tetapi pada penerapannya masih terdapat beberapa permasalahan, di antaranya: kurangnya minat guru dalam mengajar, kapasitas guru yang rendah, penguasaan kelas yang kurang efektif. Dari beberapa permasalahan yang disebutkan, peneliti tertarik untuk mengkaji permasalahan yang ada di SMK YASMIDA Ambarawa Kab. Pringsewu dengan harapan dapat memperoleh solusi yang nantinya dapat di terapkan di Lembaga Pendidikan terutama di SMK YASMIDA Ambarawa Kab. Pringsewu.

Adapun hasil wawancara penulis dengan salah satu guru yang mengatakan bahwa Guru tidak dituntut harus pintar mengajar dan mengelola kelas, tetapi guru harus bisa menciptakan suasana kelas yang nyaman. Guru tidak hanya mampu mengajar sesuai dengan keilmuan yang dimilikinya, melainkan mampu menguasai berbagai bidang, bahkan guru dituntut untuk mampu membuat humor dikelas.

Dari latar belakang permasalahan tersebut penulis tertarik untuk melakukan penelitian dengan judul "Penerapan Manajemen Sumber Daya Manusia (MSDM) dalam Meningkatkan Kinerja Guru di SMK YASMIDA Ambarawa Kab. Pringsewu".

\section{B. TUJUAN PENELITIAN}

Tujuan yang diharapkan pada penelitian ini adalah: 
"Untuk meningkatkan kinerja guru di SMK YASMIDA Ambarawa Kab. Pringsewu melalui penerapan Manajemen Sumber Daya Manusia (MSDM)".

\section{METODE PENELITIAN}

Metode Deskriptive Kualitative. Setelah mengetahui pengertian tehnik sampling, pada penelitian deskriptif kualitatif ini, peneliti menerapkan tehnik Sampling Insedental. Adapun pengertian dari Sampling Insidental. Tehnik pengumpulan data sangat dibutuhkan dalam proses penelitian di lapangan. untuk memperoleh data yang valied seorang peneliti harus menerapkan beberapa tehnik pengumpulan data. Tehnik analisis deskriptif kualitatif ini menggunakan tolak ukur dengan penerapan pengukuran dan penilaian.

\section{HASIL DAN PEMBAHASAN}

\section{Penerapan Manajemen Sumber Daya Manusia (MSDM) di SMK YASMIDA Ambarawa Kab. Pringsewu}

Penerapan Manajemen Sumber Daya Manusia di SMK YASMIDA Ambarawa Kab. Pringsewu dalam penelitian ini dapat diketahui dengan beberapa indikator, yaitu:

a. Planning (perencanaan)

Lembaga Pendidikan SMK YASMIDA Ambarawa Kab. Pringsewu setiap akan menjalankan aktifitas perlu menerapkan perencanaan. Perencanaan ini diterapkan agar tujuan yang diterapkan sesuai dengan sasaran yang diharapkan. Begitu pula dalam Penerapan Manajemen Sumber Daya Manusia (MSDM). Penerapan Manajemen Sumber Daya Manusia (MSDM) ini diterapkan agar kinerja guru yang ada di SMK YASMIDA Ambarawa Kab. Pringsewu memiliki kapasitas yang tinggi sehingga keluaran yang dihasilkan dapat bersaing dengan sekolah yang lain. Penerapan Manajemen Sumber Daya Manusia (MSDM) ini dalam perealisasiannya menerapkan perencanaan tenaga kerja yang dibutuhkan sekolah, dengan menetapkan beberapa rencana yang ditetapkan sekolah, maka kemungkinan besar hasil yang diperoleh pada saat penerimaan kinerja baru tidak akan asal-asalan. Pernyataan ini mengacu pada kalimat yang bapak kepala sekolah sampaikan pada proses wawancara berlangsung, "yaa....SMK YASMIDA memang sudah menerapkan Manajemen Sumber Daya Manusia (MSDM) sejak tahun 2014 lalu, tapi...., untuk perekrutan tenaga pendidik dan kependidikan, kita harus rapatkan kepada semua tenaga pendidik dan kependidikan dengan menetapkan rencanarencana kreteria guru yang dibutuhkan, karena sebenarnya sekolah lebih mengprioritaskan
Sumber Daya Manusia (SDM) yang ada daripada menerima tenaga pendidik dari luar sekolah, begitu mba'...".

\section{b. Organizing (organisasi)}

Penerapan pembentukan organisasi ini sangat mendukung pada program pembelajaran yang sedang berlangsung. Organisasi dibentuk untuk saling bekerja sama dengan menyetarakan mangset berzikir yang sama serta memecahkan permasalahan yang ada di sekolah secara bersama-sama. Adapun bentuk organisasi yang ada di SMK YASMIDA Ambarawa Kab. Pringsewu sebagai berikut.

Tugas utama Kepala sekolah SMK YASMIDA Ambarawa Kab. Pirngsewu diantaranya memimpin, mengarahkan dan mengatur Sumber Daya Manusia (SDM) yang ada di sekolah baik dibidang kemajuan sekolah, pemberdayaan kinerja guru, dan program yanglainnya. Selanjutnya wakil ketua bidang kurikulum (waka kurikulum) tugasnya menyusun program pembelajaran mulai dari jadwal mengajar sampai pada perealisasian belajar mengajar, dan penerapan kurikulum yang diterapkan di sekolah. Wakil ketua hubungan industry (waka hubin) tugasnya menjalankan program kerjasama dengan industry lain baik di lingkup lampung maupun diluar lampung, seperti contohnya bekerja sama dengan perusahaan Honda. Wakil ketua bidang sarana dan prasarana (waka sarpras) bertugas bertanggung jawab atas semua sarana dan prasarana yang ada di sekolah serta segala bentuk kebutuhan sarana yang dibutuhkan pada proses pembelajaran seperti menyediakan ruang serta alat untuk praktik tehnik computer jaringan (TKJ). Waka kesiswaan tugasnya mengurus agenda siswa baik di bidang organisasi maupun agenda yang diterapkan untuk kreatifitas siswa, contohnya pembentukan Organisasi Sisiwa Intra Ssekolah (OSIS), organisasi pecinta alam. Dibawahnya beberapa wakil kepala sekolah ada sekertaris yang bertugas mencatat semua agenda yang pernah berjalan selama satu tahun dan bendahara yang bertugas menghitung pendapatan serta pengeluaran sekolah. Dan yang terakhir seluruh anggota tenaga pendidik dan kependidikan di SMK YASMIDA Ambarawa Kab. Pringsewu.

\section{c. Actuating (aksi / perealisasian)}

Pada saat perealisasian untuk pengembangan kinerja guru di sekolah, kepala sekolah menerapkan pelatihan pada setiap akhir semester, pelatihan ini diwajibkan bagi semua guru SMK YASMIDA Ambarawa Kab. Pringsewu tanpa terkecuali, disamping untuk menambah wawasan serta pengetahuan dapat juga sebagai ajang silaturahmi semua guru agar rasa 
kekeluargaannya terjaga. Sesuai dengan ucapan bapak kepala sekolah pada saat wawancara, "untuk menyetarakan pola berfikir semua guru SMK YASMIDA..., saya selaku kepala sekolah selalu mendukung dan memberikan semangat kepada guru yang mempunyai kreatifitas, contohnya penerapan Kurikulum 2013. Saya kirim waka kurikulum saya untuk berangkat treanning selama satu minggu, setelah itu..., saya minta agar member pelatihan kepada semua guru SMK YASMIDA, dan... Alhamdulillah dapat berjalan sampai saat ini". Dibawah ini gambar work-shop yang berlangsung di SMK YASMIDA Ambarawa Kab. Pringsewu pada saat penerapan Kurikulum 2013.

Tidak hanya pelatihan saja yang SMK YASMIDA Ambarawa Kab. Pringsewu terapkan, melainkan mengadakan pengintregasian kepada seluruh kinerja guru yang ada di sekolah. Pengintegrasian ini sekolah terapkan setiap tahun. Agenda ini sekolah manfaatkan untuk bersama-sama beribadah sekaligus refresing semua guru SMK YASMIDA Ambarawa Kab. Pringsewu. Tidak hanya guru SMK YASMIDA saja, melainkan semua lingkungan masyarakat sekitar yang berminat berziarah kemakam wali Sembilan. Keterangan ini penulis ambil pada saat wawancara dengan bapak kepala sekolah, "ia..., kami sudah menetapkan agenda tahunan untuk berziarah kemakam Sembilan wali bersama-sama, agenda ini dapat terealisasikan bersama karna adanya kerja sama dengan PONPES YASMIDA, karena kita juga masih satu yayasan. Jadi ..., semua agenda dan peraturan yang ada disekolah, tidak lepas dari aturan yang di pondok juga,,".

Dengan menerapkan agenda-agenda SMK YASMIDA Ambarawa Kab. Pringsewu baik secara formal maupun non formal maka, sekolah menerapkan pemeliharaan tenaga kerja. Pemeliharaan tenaga kerja yang harus diterapkan di sekolah yaitu dengan memberi kebebasan kepada semua guru, agar guru dapat menjalankan tugasnya sesuai bakat dan kemampuan yang dimilikinya. Pernyataan ini peneliti ambil pada saat bapak kepala sekolah member keterangan, "kalau menurut saya, guru itu jangan sampai dituntut harus mengajar dengan berbagai macam cara, yang penting guru bersedia melakukan tanggung jawabnya, siswa nyaman belajar dikelas, guru senang mengajar di sekolah."

d. Controlling (mengontrol/mengawasi)

Kepala sekolah yang baik harus selalu mengontrol anggotanya. Kepedulian kepala sekolah terhadap semua anggota SMK YASMIDA Ambarawa Kab. Pringsewu sangat dibutuhkan demi berjalannya proses pembelajaran yang akan dilaksanakan. Proses belajar mengajar akan berjalan dengan baik dan terstruktur karena selalu ada himbauan dan arahan dari kepala sekolah. Dengan menerapkan pengontrolan aktifitas kinerja guru dalam proses pembelajaran maka, kepala sekolah dapat mengetahui apa saja kekurangan atau kelebihan kinerja guru pada saat proses belajar mengajar berlangsung.

Pengontrolan kinerja guru ini selalu sekolah terapkan agar dapat diketahui kinerja guru yang ada di SMK YASMIDA Ambarawa Kab. Pringsewu. Kinerja guru yang berkualitas serta mampu menjadi tauladan kinerja guru yang lainnya, maka akan diberi konpensasi khusus dari sekolah sebaliknya apabila ada guru yang kapasitasnya kurang mumpuni dibidangnya, maka akan diberi pelatihan khusus untuk pengutan kapasitas kinerja gurunya.

Penerapan pemberian konpensasi ini sekolah terapkan apa bila ada guru yang berhasil dalam mendidik siswa siswinya sepeti contohnya ada siswa yang juara mengikuti olimpiade tingkat kabupaten atau provinsi. Keterangan ini peneliti ambil pada saat bapak kepala sekolah memberi keterangan, "oh... pastinya..., sekolah sudah menargetkan dana khusus bagi guru yang berhak diberikan apresiasi sesuai kinerja, karena kesejahteraan guru itu kami utamakan,".

Bukan hanya kesejahteraan guru yang diterapkan SMK YASMIDA Ambarawa Kab. Pringsewu, melainkan pemutusan kinerja guru. Pemutusan kinerja ini bisa terjadi apabila ada guru yang jam mengajarnya di beberapa sekolah, sehingga ada waktu yang bersamaan akhirnya terjadilah pemutusan kinerja. Sedangkan untuk kriteria adanya pemutusan kerja, sekolah tidak akan memperhentikan guru apabila tidak ada factor-factor yang mengakibatkan guru tersebut harus berhenti, dan yang selalu terjadi guru sendirilah yang mengundurkan diri dari sekolah.

Setelah mengetahui hasil wawancara dengan Bapak Sobri Dinal Mustofa, M.Sc, dapat peneliti ambil kesimpulan bahwa penerapan Manajemen Sumber Daya Manusia (MSDM) di SMK YASMIDA Ambarawa Kab. Pringsewu dengan menerapkan planning (perencanaan), organizing (pengorganisasian), actuating (aksi/pelaksanaan) dan controlling (pengontrolan/pengawasan) dapat disingkat (POAC). Penerapan ini dapat dikategorikan cukup baik, dengan mengetahui jawaban yang sudah dipaparkan diatas bahwa di SMK YASMIDA Ambarawa Kab. Pringsewu sudah menerapkan Manajemen Sumber Daya Manusia (MSDM) dari tahun 2014 sampai tahun 2016. Sedangkan penerapannya dengan menerapkan perencanaan, pengorganisasian, pengarahan dan pengawasan dalam pengadaan 
tenaga kerja guru, pengembangan tenaga kerja guru, pemberian konpensasi kepada tenaga kerja guru, pemeliharaan terhadap guru, pemutusan hubungan kerja guru SMK YASMIDA Ambarawa Kab. Pringsewu.

\section{Kinerja Guru di SMK YASMIDA Ambarawa Kab. Pringsewu \\ Agar dapat diketahui kinerja guru di} SMK YASMIDA Ambarawa Kab. Pringsewu meningkat atau turun, maka peneliti harus mencari data dan sumber data kinerja guru dari tahun 2014, 2015 dan 2016.

Dalam proses pencarian data, peneliti menerapkan instrument pembagian angket kepada guru dan siswa serta dokumentasi. Pembagian angket ini berisi tentang pernyataan yang berkaitan dengan kinerja guru yang ada di SMK YASMIDA Ambarawa Kab. Pringsewu. Sedangkan dokumentasi ini diterapkan, guna menjadi penunjang kekuatan penelitian yang sudah dijalankan.

Ada dua bentuk angket yang dibagikan kepada responden, diantara angket siswa dan angket guru. Di bawah ini pernyataan yang peneliti buat pada saat membagikan Angket kepada Siswa SMK YASMIDA Ambarawa Kab. Pringsewu.

a. Siswa SMK YASMIDA Ambarawa Kab. Pringsewu belajar di sekolah dengan serius.

Pernyataan ini berisi tentang kinerja guru pada saat mengajar didalam kelas. Proses belajar mengajar akan berlangsung apabila tenaga pendidik dan kependidikannya dapat menciptakan kenyamanan didalam kelas. Setelah siswa sudah merasa nyaman maka, dengan sendirinya keseriusan belajar akan tercipta didalam kelas.

Setelah mengetahui hasil pernyataan ini, bahwa pada tahun 2014 dari 37 siswa, hanya 15 siswa yang belajar dikelas dengan serius, setelah proses belajar mengajar berjalan sampai tahun 2015, dan pada saat itu siswa ini sudah naik ke kelas XI, ternyata dapat diketahui hasilnya bahwa 20 siswa yang belajar di kelas dengan serius, setelah naik ke kelas XII karena akan memasuki ujian agar dapat diketahui lulus atau tidaknya, maka pada tahun 2016 ini siswa 37 belajar dengan serius.

Melihat hasil pernyataan angket yang sudah diperoleh, dapat peneliti ambil kesimpulan bahwa dari tahun 2014, 2015 dan 2016 ternyata kinerja guru di SMK YASMIDA Ambarawa Kab. Pringsewu dalam proses belajar mengajarnya terdapat peningkatan, dengan demikian untuk lebih jelasnya lihat diagram batang dibawah ini.

b. Guru SMK YASMIDA Ambarawa

Kab. Pringsewu masuk kelas pada waktu yang tepat.
Pernyataan ini berisi tentang tenaga kerja seorang pendidik dan kependidikan berkaitan dengan kedisiplinan mengajar di kelas. Kedisiplinan ini harus selalu dilestarikan serta diterapkan sebagai budaya yang ada di SMK YASMIDA Ambarawa Kab. Pringsewu. Kehadiran guru di kelas sangat diharapkan siswa-siswi SMK YASMIDA Ambarawa Kab. Pringsewu. Dengan kehadiran guru pada waktu yang tepat, membuat peserta didik menumbuhkan semangat pada proses belajar mengajar yang akan berlangsung.

Pendeskripsian diatas sama dengan pendeskripsian pada penelitian Kusuma dan Purwanti (2017) Kompetensi pedagogik dan manajemen pembelajaran yang dimaksudkan adalah bagaimana seorang guru ataupun dosen memiliki kapasitas keahlian yang sesuai dengan apa yang diajarkan serta bagaimana seorang guru atau dosen mampu menyampaikan materi yang diajarkan sesuai dengan yang direncanakan sesuai keahlian dan materi pembelajaran yang diampunya, seperti menyusun silabus, membuat perangkat pembelajaran, menguasai metodhe dan strategi pembelajaran, menguasai media pembelajaran, yang pada intinya bagaimana seorang guru atau dosen mampu menguasai kelas sehingga tercapai tujuan pembelajaran yang di inginkan. Hal tersebut mendukung pernyataan diatas bahwa dengan guru menguasai kelas, maka proses pembelajaran akan berlangsung secara baik.

Setelah peneliti mengetahui jawaban dari pernyataan yang diberikan siswa, dapat diketahui bahwa dari 37 siswa menyatakan bahwa ditahun 2014 siswa yang berpendapat guru masuk kelas pada waktu yang tepat ada 10 siswa, sedangkan pada tahun 2015 siswa yang menyatakan guru masuk kelas pada waktu yang tepat ada 20 orang, setelah mencapai tahun 2016 siswa yang menyatakan guru masuk kelas pada waktu yang tepat ada 30 siswa.

\section{E. PENUTUP}

\section{1) Kesimpulan}

Berdasarkan hasil penelitian dan pembahasan dapat disimpulkan sebagai berikut:

1. Pada penerapan Manajemen Sumber Daya Manusia (MSDM) dalam meningkatkan kinerja guru di SMK YASMIDA Ambarawa Kab. Pringsewu dapat dikategorikan sangat baik, dengan alasan melihat proses penerapan Pleanning, Organizing, Actuating, Controlling, (POAC) dalam proses pengadaan, pengembangan, pemberian konpensasi, pengintegrasian, pemeliharaan dan pemutusan hubungan kerja terhadap semua tenaga pendidik dan kependidikan di SMK YASMIDA Ambarawa Kab. Pringsewu. 
2. SMK YASMIDA Ambarawa Kab. Pringsewu merupakan sekolah rujukan dalam penerapan Kurikulum 2013, dengan menerapkan standar kinerja bagi tenaga pendidik dan kependidikan meliputi: gaji yang disepakati oleh yayasan, sarana dan prasarana yang memadai, lingkungan fisik yang mendukung dan kepemimpinan kepala sekolah yang professional.

3. Setelah penelitian di SMK YASMIDA Ambarawa Kab. Pringsewu terealisasikan, maka peneliti dapat mengetahui hasil yang diperoleh pada saat di lapangan. Adapun bahan yang dicari yaitu terkait Kinerja guru di SMK YASMIDA Ambarawa Kab. Pringsewu terhitung dari tahun 2014 sapai tahun 2016. Kinerja guru di SMK YASMIDA Ambarawa Kab. Pringsewu termasuk kategori cukup baik, maka untuk itu sebagai acuannya dengan melihat hasil yang diperoleh peneliti pada saat membagikan angket pernyataan kepada siswa dan guru dengan hasil yang sama (belens) yaitu sama-sama mengalami peningkatan cukup baik.

\section{2) Saran}

Berdasarkan hasil penelitian yang sudah berlangsung, peneliti menyarankan:

1. Bagi kepala Sekolah, pada saat menerapkan Manajemen Sumber Daya Manusia (MSDM) dalam meningkatkan kinerja guru di SMK YASMIDA Ambarawa Kab. Pringsewu harus mengetahui kemampuan kinerja guru masingmasing tenaga pendidik dan kependidikan, agar pada proses penerapannya tidak terlalu merasa banyak hambatan dan kendala yang dihadapi, serta tidak salah sasaran pada peletakan tugas dan tanggung jawabnya sebagai tenaga pendidik dan kependidikan.

2. Bagi tenaga pendidik dan kependidikan, pada saat akan menjalankan tugas sebagai seoarang pendidik harus mengetahui peraturan UUD No.14 tahun 2005 tentang guru dan dosen, agar tidak menyalahi aturan pemerintah. Serta seorang guru harus dapat mengoprasikan computer dengan tujuan supaya tidak tertinggal pada proses belajar mengajar, serta mampu bersaing terhadap lembaga pendidikan yang lain dan tidak tertinggal dengan teknologi yang ada dimasa kini dan masa yang akan datang.

\section{DAFTAR PUSTAKA}

Al-Wasilah, Pokok-pokok penelitian Kualitatif, Dunia Pustaka Jaya, Jakarta: 2006.

Andang.2014. Manajemen dan Kepemimpinan Kepala Sekolah. Yogyakarta: ArRuzz Media.

Arikunto Suharmisi. 2002. Prosedur Penelitian Suatu Pendekatan Praktik. Jakarta: Rineka Cipta,

B. Flippo Edwin \& Handoko. 2009. Manajemen Sumber Daya Manusia. Yogyakarta: Graha Ilmu,

Barnawi \& Mohammad Arifin. 2014. Kinerja Guru Profesional. Jogjakarta: Ar-Ruzz Media,

Beradin \& Russel.2009.Manajemen Sumber Daya Manusia. Yogyakarta: Graha Ilmu.

Costello. 2013. Manajemen Kinerja. Jakarta: Rajawali Pers,

Faisal Sanapiah, Penelitian Kualitatif Dasar-

Dasar dan Aplikasi. IKIP, Malang: 1990.

Gibson. 2006. Peran Kepala Sekolah dalam Meningkatkan Mutu Pendidikan. Jatinanggor Sumendang: Al qaprint.

Gomes dkk. 2014. Kinerja Guru Profesional. Yogyakarta: Ar-Ruzz Media,

H.radsky John L. 2006. Peran Kepala Sekolah dalam Meningkatkan Mutu Pendidikan. Jatinanggor Sumendang: Al qaprint.

Haiman. 2013. Manajemen Itu Mudah. Jakarta: PT Rajagrafindo Persada,

http:/id.shvoong.com/business.management/233 185-definisi-management-serta 10 jenis.

Koontz Harold \& Cyril O. Donnel.2009. Manajemen Sumber Daya Manusia. Yogyakarta: Graha Ilmu.

Kusuma, N., \& Purwanti, E. 2017. Pengaruh Kompetensi Pedagogik Dan Manajemen Pembelajaran Terhadap Penjaminan Mutu Pada Universitas Sang Bumi Ruwa Jurai Lampung. Indonesian Journal of Educational Counseling, 1(2), 209-226.

Kreitner Robert \& Angelo Kinichi. 2006. Peran Kepala Sekolah dalam Meningkatkan Mutu Pendidikan. Jatinanggor Sumendang: Al qaprint.

Lincolin \&Guba, Pokok-pokok Penelitian Kualitatif (AL-Wasilah), Dunia Pustaka Jaya, Jakarta: 2006.

N. Kinggundu Mosen. 2009. Manajemen

Sumber Daya Manusia. Yogyakarta: Graha Ilmu, 
Nasution, Metode Research (Penelitian Ilmiah), Bumi Aksara, Jakarta: 2003

Noor Juliansyah. 2012. Metodologi Penelitian. Jakarta: Kencana,

Palmatier L. Larry.2006.Peran Kepala Sekolah dalam Meningkatkan Mutu Pendidikan. Jatinanggor Sumendang: Al qaprint.

Pfifner M.Johan.2009. Manajemen Sumber Daya Manusia. Yogyakarta: Graha Ilmu.

R.Terry George. 2013. Manajemen Itu Mudah. Jakarta: PT Rajagrafindo Persada,

Rahman et.al.2006. Peran Kepala Sekolah dalam Meningkatkan Mutu Pendidikan. Jatinanggor Sumendang: Al qaprint.

Rasito Hermawan, Pengantar Metodologi

Penelitian, Gramedia Pustaka Umum, Jakarta: 2004.

Schwartz. 2013. Manajemen Kinerja. Jakarta: Rajawali Pers,

Siagian P. Sondang.2014. Manajemen dan Kepemimpinan Kepala Sekolah. Yogyakarta: Ar-Ruzz Media.

Stoner. 2013. Manajemen Itu Mudah. Jakarta: PT. Rajagrafindo Persada,

Suharti Eni. 2008. Undang-undang Guru dan Dosen. Jakarta: Sinar Grafika,

Teguh Ambar Sulistiani Rosidah. 2009. Manajemen Sumber Daya Manusia. Yogyakarta: Graha Ilmu,

Tjutju \& Suwarto. 2014. Kinerja Guru Profesional. Yogyakarta: Ar-Ruzz Media,

Tulus.2009.Manajemen Sumber Daya Manusia.Yogyakarta:Graha Ilmu.

Wibowo. 2013. Manajemen Kinerja. Jakarta: Rajawali Pers, 